\title{
Antidiarrheal activity of crude methanolic root extract of Idigofera spicata Forssk.(Fabaceae)
}

\author{
Eshetie Melese Birru*, Assefa Belay Asrie, Getnet Mequanint Adinew and Asegedech Tsegaw
}

\begin{abstract}
Background: Till now many of medicinal plants having claimed therapeutic value traditionally are waiting scientific verification of their efficacy and safety. Accordingly this study is conducted to evaluate the antidiarrheal activity of hydromethanolic root extract of Indigofera spicata Forssk. in castor oil induced diarrhea model, misoprostol induced secretion model and its antimotility activity using charcoal as a marker.

Methods: In all the three models the animals were randomly allocated into five groups of six animals each and then group I mice were received $1 \mathrm{ml} / 100 \mathrm{~g}$ normal saline, group II were treated with standard drug as a positive control whereas group III, IV and V were treated with 100, 200 and $400 \mathrm{mg} / \mathrm{kg}$ extract doses, respectively. Statistical significance of differences in the mean of number of defecations, fluid content of faces, intestinal fluid accumulation ratio, intestinal fluid weight and distance travelled by charcoal between groups was analyzed by SPSS version-21 using one way ANOVA followed by Tukey's post hoc multiple comparison.

Result: The hydromethanolic crude extract of Indigofera spicata at 200 and 400 mg/kg mg/kg doses showed statistically significant $(p<0.05)$ inhibition of the frequency of defecation and weight difference of the fluid content of the faces compared to the negative controls. For those doses the percentage inhibition of diarrheal feces was 43.62 and $53.51 \%$, respectively. The antisecretary activity of the extract in terms of fluid accumulation ratio was not found significant but in terms of intestinal fluid weight, all the extract doses revealed significant $(p<0.05)$ inhibition. Unlike the standard drug, the antimotility activity of the extract was not found statistically significant compared to the negative control.
\end{abstract}

Conclusion: Root of Indigofera spicata Forssk. has shown promising antidiarrheal activity which validates its traditional use. Further studies are needed and possibly the plant may serve as a potential source of new agent in the therapeutic armamentarium of diarrhea.

Keywords: Antidiarrheal, Indigofera spicata, Castor oil, Ethnopharmacology

\section{Background}

Diarrhea is generally defined as the passage of abnormally liquid or unformed stools associated with increased frequency of defecation, and abdominal pain [1]. Despite reductions in morbidity and mortality worldwide, diarrhea still accounts for more than 2 million deaths annually and is associated with impaired physical and cognitive development in resource-limited countries

\footnotetext{
* Correspondence: meshetie21@gmail.com

Department of Pharmacology, College of Medicine and Health Sciences, University of Gondar, Chechela street, Lideta subcity kebele 16, Gondar, Ethiopia
}

$[2,3]$. This is more significant in case of infants and children for instance in developing countries, diarrhoeal disease accounts for an estimated $17.5-21 \%$ of all deaths in children under the age of 5 years, equivalent to 1.5 million deaths per year. Of all child deaths from diarrhoea, $78 \%$ occur in the African and South-East Asian regions, creating a tremendous economic strain on The existence of unique geographic, economic, political, sociocultural, and personal factors in sub-Saharan region interact to create distinctive continuing challenges to diarrhea prevention and control. Consequently, 
approximately $40 \%$ of childhood deaths from diarrhea worldwide will occur in Sub-Saharan Africa by the year 2000, although only $19 \%$ of the world's population under the age of 5 years will live in this region. This continuing epidemic deserves sustained programmatic and research attention as international public health moves on to confront newer issues in infectious disease and the changing burdens of disease associated with the demographic transition $[5,6]$.

Medicinal plants are usually preferred to treat gastrointestinal disorders, for example, constipation and diarrhea, because they contain multiple constituents with effect-enhancing and/or side effect-neutralizing potential [7] and, hence are considered relatively safe in prolonged use. There has been increased global interest in traditional medicine and there are efforts underway to monitor and regulate herbal drugs and traditional medicine [8]. Due to reliance of the society of resource limited areas still on herbal medicine for their health care needs WHO recommended the integrated use of folk and modern medicine for controlling of health problems [9].

Like other developing countries, people in Ethiopia strongly rely on therapeutic benefits of traditional medicine. Accordingly, ethnobotanical survey studies reported that there are a number of plants which do have claimed antidiarheal role but scientific therapeutic and safety evaluations on some of these herbs such as Indigofera spicata Forssk. have not been reported [10-12].

Indigofera species posses multiple uses ranging from several economical and ecological roles, feed for livestock, ornamental, medicinal plant recipes as well as dye for commercial purpose. In this genus and family Fabaceae, the flowering herb Indigofera spicata Forssk. is traditionally useful for the treatment of meningitis, diarrhea, stomachache, diabetes and other health problems [10-16]. Apart from a number of ethnomedicine survey reports of this plant therapeutic usefulness for diarrhea and stomachache [10-12, 15], pharmacologically Indigofera spicata has reported in vitro antioxidant, cytotoxic and antibacterial [17-19] and in vivo antidiabetic activity [16]. It is stated that diarrhea impairs intestinal antioxidant defense system which will make it complicated and induce other oxidative stress disorders and therefore antioxidants may take up important application in the management of diarrhea [20-22]. Even though there is no detail study on the phytoconstituents of this plant previous works $[16,17]$ reported that this plant contains alkaloids, flavnoids, tannins, steroids and others most of which do have known antidiarrheal activity [23, 24]. Thus, considering all these the present study is aimed at pharmacologic verification of the antidiahreal activity of Indigofera spicata Forssk. using animal model that may give us a clue to enlighten on its efficacy for diarrhea and the essence of further investigations.

\section{Methods}

\section{Plant material}

The roots of Indigofera spicata (IS) were collected from Shawra and its surounding area, South West Gondar province, North West Ethiopia in December, 2014. Taxonomic identification was done by a botanist (Mr. Abiyu Enyew, Plant biology and biodiversity (PHD candidate), Addis Abeba Univesity) and a voucher specimen (EM001) is already deposited in the Department of Biology, National Herbarium, Addis Ababa University.

\section{Experimental animals}

Healthy male Swiss albino mice, weighing between 22$32 \mathrm{~g}$ and 6 to 8 weeks old, were obtained from animal house of Department of Pharmacology, University of Gondar. They were housed in plastic cages with softwood shavings and chips as beddings. They were maintained under standard condition of relative humidity, temperature and $12 \mathrm{~h}$ light $/ 12 \mathrm{~h}$ dark cycle and given food and water ad labtium. All mice were acclimatized to the working environment 1 week before the beginning of pharmacologic activities evaluation $[25,26]$.

\section{Extraction procedure}

The fresh roots of Indigofera spicata Forssk. were thoroughly washed with distilled water to remove dirt and soil, and dried under shade and optimal ventilation for 2 weeks. The dried roots were further chopped into small pieces and reduced to powder using electronic miller. The coarsely powdered roots were subjected to maceration extraction procedure using $80 \%$ methanol (for $72 \mathrm{~h}$ at room temperature) as a menstruum and this was done three times. The respective extract was filtered using Whatman No-1 filter paper and the solvent was evaporated in an oven under reduced pressure at $40{ }^{\circ} \mathrm{C}$. Finally the dried extract was stored at $4{ }^{\circ} \mathrm{C}$ in refrigerator.

\section{Prelimnary phytochemical screening}

The presence and absence of secondary plant metabolites in the crude hydromethanolic root extract of Indigofera spicata was screened by color forming and precipitation assays using standard procedures [27, 28].

\section{Acute toxicity}

As per the OECD guideline, acute oral toxicity was determined by using the limit dose of $2000 \mathrm{mg} / \mathrm{kg}$ body weight of the mice [26].

\section{Animal grouping and dosing}

In all models the mice were randomly grouped $(n=6)$ and the substances administered were as follows:

Group I: received $1 \mathrm{ml} / 100 \mathrm{mg}$ normal saline (NS). 
Group II: treated with standard drug, $3 \mathrm{mg} / \mathrm{kg}$ lopiramide (3 $\mathrm{mg} / \mathrm{kg}$ Lop) in both castor oil induced antidiahreal test and misoprostol induced antisecretory test and atropine sulfate $0.1 \mathrm{ug} / \mathrm{g}$ IP for gastrointestinal motility test.

Group III: treated with $100 \mathrm{mg} / \mathrm{kg}$ extract $(100 \mathrm{mg} / \mathrm{kg}$ ISP).

Group IV: treated with $200 \mathrm{mg} / \mathrm{kg}$ extract $(200 \mathrm{mg} / \mathrm{kg}$ ISP).

Group V: treated with $400 \mathrm{mg} / \mathrm{kg}$ extract $(400 \mathrm{mg} / \mathrm{kg}$ ISP).

The test doses of the extract were selected based on the acute toxicity study result. Volume to be administered was also determined based on OECD guideline which states $1 \mathrm{ml} / 100 \mathrm{~g}$ of body weight of the animal [26]. As people traditionally use the preparations of the plant extract via oral route using water as a vehicle $[9,10]$ the study was conducted using oral route of administration except the intraperitoneal injection of atropine, standard drug.

\section{Antidiarrheal activity evaluation of $\mathbf{8 0} \%$ methanolic root extract of $I$. spicata}

In doing this, three antidiarrheal activity evaluation models were used. The first was the castor oil induced diarrheal model which is helpful to evaluate the overall possible antidiarrheal activity of the plant material. And this was followed by the attempt of investigating the antidiarrheal mechanism of action of the plant extract i.e. either by inhibition of intestinal transit and/or antisecretary activity.

\section{Castor oil induced model}

The assimilation of methods described by Shoba [29] and Franca [30] with modifications were followed for this study. Only animals which were found diarrheic when they have taken $0.5 \mathrm{ml}$ castor oil in the initial screening test were included in this experiment. Mice fasted for $24 \mathrm{~h}$ were randomly allocated to five groups of six animals each. For the induction of diarrhea $0.5 \mathrm{ml}$ castor oil was given for each mouse $30 \mathrm{~min}$ before treatment. Each animal was then placed in individual cage, the floor of which was lined with transparent paper and every hour the floor lining was changed. Onsets of diarrhea, total number of fecal outputs within in the $4 \mathrm{~h}$ period were recorded. And even total fluid content of the faces was determined by using the weight difference of the fresh and dry stool (dried for $24 \mathrm{~h}$ at room temperature in a shaded area). Evacuation classification based on stool consistency was assigned as follows: normal stool $=1$, semi-solid stool $=2$ and watery stool $=3$ and mean of evacuation index (EI) was calculated for each group [31]. For all the groups the percentage inhibition of diarrhea was also calculated compared to the negative controls.

\section{Gastrointestinal motility test by charcoal meal}

The mice were first fasted for $18 \mathrm{~h}$, but had free access to water. After the grouping, the respective groups were treated as mentioned above. After $1 \mathrm{~h}$ each animal was loaded with $1 \mathrm{ml}$ of $3 \%$ deactivated charcoal in normal saline and then waited for $1 \mathrm{~h}$ and dissected. The small intestine (from pylorus to caecum) was removed and its length was measured. The intestinal charcoal transit was expressed as a percentage of the distance moved by charcoal to the total length between the pylorus and the caecum [32]. The known spasmolytic agent, atropine was used as a standard drug for positive control group.

\section{Antisecretary assay}

Prostaglandins $\left(\mathrm{PGE}_{2}\right)$ induce intestinal secretion and this is helpful to evaluate antisecretary activity of different chemical compounds [33, 34]. Thus, in this model the mice were first fasted for $24 \mathrm{~h}$ and then received $20 \mathrm{ug} / \mathrm{kg}$ misoprostol for the induction of intestinal secretion. After $1 \mathrm{~h}$ each group of mice were treated just like the above castor oil induced diarrhea model. The animals were then sacrificed after $24 \mathrm{~h}$ by cervical dislocation, laparotimized, and then the pyloric and caecal ends of the small intestine were tied and removed. For each animal fluid accumulation ratio (the weight of intestine to the rest of the body weight of mouse) was determined and the antisecretory activity was expressed in percentage of inhibition [35]. The weight of the fluid content of the removed intestine was also determined by subtracting the weight of the intestine before and after milking of the removed intestine.

\section{Statistical analysis}

All the experimental data are expressed as mean \pm Standard error of means. For data processing and analysis SPSS statistical software Version 21.0 was used. Statistical significance of differences between groups was assessed by One-way ANOVA followed by post-hoc Tukey's multiple Comparison Test. The results were considered significant at $p$-value less than 0.05 .

\section{Ethical clearance}

All the experimental animals were handled and used according to the animal care and welfare guidelines $[25,26,36]$. The experimental protocols were requested to and approved by the Institutional Review Board of the College of Medicine and Health Sciences, University of Gondar and ethical clearance was obtained from the research and publication office of the University. 


\section{Result}

\section{Extract material}

The final dried hydromethanolic root extract of Indigofera spicata was brown powder in its color and the yield was $12.53 \%$.

\section{Phytochemical screening result}

The preliminary phytochemical screening test results on the selected secondary plant metabolites are summarized in Table 1.

\section{Oral acute toxicity}

The oral acute toxicity test by using the limit dose of $2000 \mathrm{mg} / \mathrm{kg}$ body weight of the mouse found safe because at this dose the animals didn't show any observable physical and behavioral changes, confirming that the LD50 of the extract is greater than $2000 \mathrm{mg} / \mathrm{kg}$.

\section{Andiarrheal acitivity evaluations}

\section{Effect of the extract on the castor oil induced diarrhea}

Considering the latency of defecation after castor oil supplementation, only the $400 \mathrm{mg} / \mathrm{kg}$ extract dose treated groups demonstrated significant $(p<0.01)$ delay compared to the negative controls. The onset of defecation in this group was also found significantly $(p<0.05)$ different compared to the 100 and $200 \mathrm{mg} / \mathrm{kg}$ extract dose treated groups. Like that of the standard drug, the hydromethanolic crude extract doses (200 and $400 \mathrm{mg} / \mathrm{kg}$ ) of root of Indigofera spicata as it is sown in Table 2 showed statistically significant $(p<0.05)$ inhibition both in the frequency of defecation and total weight of the fluid content of the faces compared to the negative controls. The percentage inhibition of diarrhea by the 100 , 200 and $400 \mathrm{mg} / \mathrm{kg}$ doses of the extract was determined $22.49,43.62$ and $53.51 \%$, respectively. And this inhibition, especially from the largest dose of extract was comparable with the inhibitory effect (51.02\%) of lopiramid. Neither the positive control nor the extract treated groups exhibited statistically significant difference in the mean

Table 1 Preliminary phytochemical screening result of crude hydromethanolic root extract of Indigofera spicata

\begin{tabular}{lc}
\hline Test & Result \\
\hline Alkaloids & + \\
Tannins & + \\
Saponins & + \\
glycosides & + \\
Flavonoids & + \\
Phenolic compounds & - \\
Steroidal compounds & + \\
Terpenoids & + \\
\hline
\end{tabular}

+ refers presence and - refers absence evacuation index compared to the normal saline exposed groups. The mean evacuation index didn't show apparent difference among any of the groups.

\section{Gastrointestinal motility test}

Regarding spasmolytic activity, all the extract dose treated groups didn't show significant difference compared to the negative control and amongst each other. But the atropine treated group showed statistically significant $(p<0.001)$ inhibition of intestinal motility compared to both the negative control and all the extract treated groups as it is illustrated in Table 3. Compared to the normal saline exposed group, the percentage inhibition of intestinal transit from atropine and the largest dose of the extract $(400 \mathrm{mg} / \mathrm{kg})$ were found 68.45 and $11.24 \%$, respectively.

\section{Anti-secretary activity}

The antisecretary activity of the extract on misoprostol induced GI secretion according to the fluid accumulation ratio unlike that of lopiramide was found statistically insignificant compared to the negative control. As it is shown in Table 4 the percentage inhibition of intestinal fluid accumulation ratio of the extract is inversely related to its dose. Nevertheless, the weight of the intestinal fluid in all the respective extract doses treated groups was found significantly $(p<0.01)$ lower than the negative control and this was comparable with the lopiramide treated group.

\section{Discussion}

In so many areas in Ethiopia Indigofera spicata is used for the treatment of different health problems including diarrhea [9-15] without scientific substantiation of its safety and efficacy. The safety issue is highly important because this plant has demonstrated hepatotoxic, abortifacient like and teratogenic effects in animals [37-39].

Diarrhea may occur when there is a change in active ion transport by decreased sodium absorption or increased chloride secretion, change in intestinal motility, increase in luminal osmolarity; and/or increase in tissue hydrostatic pressure [40]. From all these mechanisms castor oil via its active compound ricinoleic acid induces diarrhea by stimulating secretory processes and intestinal motility secondary to irritation and inflammation [41]. The antidiarrheal agents act by inhibiting one or more of the aforementioned pathophysiologic processes.

Basically in folk medicine root of Indigofera spicata is used for treatment of diarrhea by using water as a vehicle but here in this study we used $80 \%$ methanol because hydromethanolic solvents (especially $80 \%$ methanol) are usually better and more efficient in extracting the most important bioconstituents of the plant material which is owing to their expanded polarity 
Table 2 Effect of crude hydromethanolic extract of root of Indigofera spicata on castor oil induced diarrhea in mice

\begin{tabular}{lccccc}
\hline Group & Onset of diarrhea (min) & $\begin{array}{l}\text { Total number of faeces in } 4 \mathrm{~h} \\
\text { (frequency of defecation in } 4 \mathrm{~h} \text { ) }\end{array}$ & Mean evacuation index & $\begin{array}{c}\text { Fluid content of the faces (g) } \\
\text { \% Inhibition of } \\
\text { diarrhea }\end{array}$ \\
\hline NS & $63.33 \pm 5.58$ & $11.83 \pm 1.30$ & $2.39 \pm 0.09$ & $0.78 \pm 0.13$ & 0.00 \\
$3 \mathrm{mg} / \mathrm{kg} \mathrm{Lop}$ & $99.17 \pm 18.14$ & $5.83 \pm 0.75^{*}$ & $2.29 \pm 0.15$ & $0.36 \pm 0.05^{*}$ & 51.02 \\
$100 \mathrm{mg} / \mathrm{kg} \mathrm{IS}$ & $71.83 \pm 5.67$ & $9.17 \pm 0.70$ & $2.34 \pm 0.06$ & $0.61 \pm 0.11$ & $0.32 \pm 0.09^{*}$ \\
$200 \mathrm{mg} / \mathrm{kg} \mathrm{IS}$ & $75.33 \pm 4.86$ & $6.67 \pm 1.52^{*}$ & $2.17 \pm 0.08$ & $0.35 \pm 0.08^{*}$ & 43.62 \\
$400 \mathrm{mg} / \mathrm{kg}$ IS & $121.17 \pm 12.18^{* \mathrm{ab}}$ & $5.50 \pm 0.67^{*}$ & $1.96 \pm 0.16$ & 53.51 \\
\hline
\end{tabular}

Values are mean \pm S.E. $(n=6),{ }^{*}$ for $p<0.05$ compared to the negative control, ${ }^{a}$ for $p<0.05$ compared to $100 \mathrm{mg} / \mathrm{kg} \mathrm{IS} \mathrm{and}{ }^{\mathrm{b}}$ for $p<0.05$ compared to $200 \mathrm{mg} / \mathrm{kg}$ IS

range. By virtue of the cosolubility, many compounds, which are insoluble individually in pure state in methanol could be extracted quite easily with hydroalcoholic solvents [42-44].

Here in the oral acute toxicity test as per the $2000 \mathrm{mg} / \mathrm{kg}$ limit dose of the OECD guideline was performed to get a clue of the appropriate safe dose range that could be used in evaluating the antidiarrheal activity of the extract in different models instead of clarifying all the toxicity profile of the crude extract. Accordingly in agreement with the previous oral acute toxicity report of this plant leaves extract [16] and other species of genus Indigofera [45] the LD50 of crude hydromethanolic root extract of Indigofera spicata was found greater than $2000 \mathrm{mg} / \mathrm{kg}$ body weight of the animal.

As it shown in Table 2 in the castor oil induced diarrhea the root extract of Indigofera spicata inhibits frequency of defecation and fluid content of stool more likely in a dose dependent manner. For instance with in $4 \mathrm{~h}$ period of post castor oil exposure, the frequency of defecation and fluid content of the stool unlike the $100 \mathrm{mg} / \mathrm{kg}$ in those treated with 200 and $400 \mathrm{mg} / \mathrm{kg}$ extract doses there was statistically significant difference (i.e. inhibition) compared to the normal saline exposed mice. The percentage inhibition of frequency of defecation from the $400 \mathrm{mg} / \mathrm{kg}$ dose of the extract is $53.51 \%$ which is nearly equivalent with $51.02 \%$ of the positive control. This antidiarrheal activity of Indigofera spicata in a dose dependent manner makes it more similar with other plant extracts [46]. However, the mean evacuation index didn't have statistically apparent difference among all groups which may be due to small sample size and/or methodologic limitation in designating evacuation based on stool consistency.

Contrasting to the antidiarrheal activity of the extract in the castor oil induced diarrhea model, its activity on intestinal motility was not found statistically significant $(p>0.05)$ and its is confirmed that the plant material don't have essential antimotility activity. However, considering the percentage inhibition of intestinal transit as it is shown in Table 3 as the dose increased by two fold the response also increased by more than two fold and hence the extract still do have dose dependent activity in this model.

In the antisecretary activity evaluation only the intestinal fluid accumulation ratio of lopiramide treated group was found statistically significant compared to the negative controls. But in this model the weight of the intestinal fluid (i.e. determined by taking the weight difference of the dissected intestine before and after $24 \mathrm{~h}$ ) like the positive control in all the extract dose treated groups shown significant difference $(p<0.05)$ compared to the normal saline exposed mice. Furthermore, the percentage inhibition of intestinal fluid accumulation ratio by 100,200 , and $400 \mathrm{mg} / \mathrm{kg}$ doses of the extract was determined to be $19.21,17.27$ and $11.81 \%$ respectively. This tells us the presence of noticeable relationship between the dose and response of the extract. In this misoprostol induced intestinal secretion model the antisecretary activity of the plant demonstrated inversely associated dose-response relationship. To the contrary as it is shown in the castor oil induced model the antidiarrheal activity of the larger doses is better than the lower dose of the extract. This could be explained by difference in

Table 3 Effect of crude hydromethanolic root extract of root of Indigofera spicata on intestinal motility using charcoal as a marker in mice

\begin{tabular}{lcccc}
\hline Group & Total intestinal length $(\mathrm{cm})$ & Distance travelled by charcoal $(\mathrm{cm})$ & \% Intestinal transit of charcoal & \% Inhibition \\
\hline NS & $55.67 \pm 2.16$ & $49.67 \pm 2.06^{t+}$ & $89.23 \pm 1.26^{\dagger+}$ & 2.00 \\
Atropine & $57.83 \pm 1.14$ & $16.33 \pm 1.78$ & $28.15 \pm 2.90$ & 68.45 \\
$100 \mathrm{mg} / \mathrm{kg}$ IS & $54.17 \pm 2.15$ & $47.67 \pm 1.45^{\dagger+}$ & $88.21 \pm 1.62^{\dagger+}$ & $85.13 \pm 3.47^{\dagger+}$ \\
$200 \mathrm{mg} / \mathrm{kg} \mathrm{IS}$ & $53.17 \pm 1.54$ & $45.17 \pm 1.89^{\dagger+}$ & $79.20 \pm 3.11^{\dagger+}$ & 4.59 \\
$400 \mathrm{mg} / \mathrm{kg}$ IS & $58.33 \pm 1.36$ & $46.17 \pm 1.94^{\dagger+}$ & 11.24 \\
\hline
\end{tabular}


Table 4 Effect of crude hydromethanolic extract of root of Indigofera spicata on misoprostol induced Gl secretion in mice

\begin{tabular}{lcccc}
\hline Group & Weight of small intestine (g) & Intestinal fluid accumulation ratio & Weight of intestinal fluid (g) & $\begin{array}{c}\text { \% Inhibition of intestinal fluid } \\
\text { accumulation ratio }\end{array}$ \\
\hline NS & $1.94 \pm 0.52$ & $0.109 \pm 0.008$ & $0.4567 \pm 0.11$ & 0.00 \\
$3 \mathrm{mg} / \mathrm{kg} \mathrm{Lop}$ & $1.38 \pm 0.81$ & $0.084 \pm 0.004^{*}$ & $0.1567 \pm 0.01^{*}$ & 22.81 \\
$100 \mathrm{mg} / \mathrm{kg} \mathrm{IS}$ & $1.46 \pm 0.35$ & $0.088 \pm 0.004$ & $0.1367 \pm 0.03^{*}$ & 19.21 \\
$200 \mathrm{mg} / \mathrm{kg} \mathrm{IS}$ & $1.45 \pm 0.67$ & $0.090 \pm 0.006$ & $0.1383 \pm 0.01^{*}$ & 17.27 \\
$400 \mathrm{mg} / \mathrm{kg}$ IS & $1.59 \pm 0.41$ & $0.096 \pm 0.005$ & $0.1650 \pm 0.03^{*}$ & 11.81 \\
\hline
\end{tabular}

Values are mean \pm S.E. $(n=6),{ }^{*}$ for $p<0.05$ compared to the negative control

secretion induction mechanism of castor oil and misoprostol that may affect the antidiarrheal activity of the plant extract. Furthermore, considering lack of significant antimotility activity and antisecretary activity using intestinal fluid accumulation ratio as a parameter but not in terms of weight of intestinal fluid there may be a possibility of the plant extract to have antidiarrheal activities via adsorbent like mechanism of action. In conclusion, the antidiarrheal mechanism of action of the extract need to be investigated further since the overall finding of this study never address the definitive mechanism.

Regarding the preliminary phytochemical screening in agreement with the previous report on its leaves extract [16] and related species [45] in the crude hydromethanolic root extract of Indigofera spicata the test was found positive for alkaloids, flavonoids, tannins, glycosides, saponnins and some other secondary plant metabolites as it is depicted in Table 1. And these secondary plant metabolites have known antidiarrheal activity independently or synergistically [23].

Among plant phytochemicals it is reported that tannins reduce diarrhea by reducing intestinal secretion mediated by the denaturation of secretary proteins and inhibiting the motility of intestine via altering the intracellular $\mathrm{Ca}^{+2}$ level [24]. Likewise, flavnoids are also known intestinal motility and water and electrolyte secretion inhibitors and even they do have antioxidant activity which may have a role in suppressing the catalytic activity of different enzymes including enzymes for the synthesis of prostaglandins [22, 47]. Parallel to this fact it is reported that Indigofera spicata do have antioxidant and cytotoxic activity $[17,18]$ that may have a role in its antidiarrheal mechanism of action. Furthermore, steroids may also enhance the absorption of hydroelectrolytes across the intestinal lumen $[23,48]$. Thus the demonstrated biologic antidiarreal activity of hydromethanolic crude root extract of Indigofera spicata might be due to the presence of the aforementioned secondary plant metabolites.

\section{Conclusion}

In conclusion this study verified that other than being safe up to a dose of $2000 \mathrm{mg} / \mathrm{kg}$, hydromethanolic crude root extract of Indigofera spicata Forssk. has antidiarrrheal activity. Accordingly, the study validates traditional use of the plant for diarrhea and may guide us to use it as a potential source of new agent in the therapeutic armamentarium of diarrhea.

\section{Acknowledgement}

First we all authors are so thankful for University of Gondar for funding of this study. Next our gratitude will goes to Mr. Zemene Demelash and Miss. Banchamlak Demamu for their unreserved technical support in all the research activities.

\section{Funding}

After preparing the proposal fund was requested to and obtained from University of Gondar. Then after the authors accomplished all the study tasks.

Availability of data and material

The descriptive result of misoprostol induced secretion model.

\section{Authors' contributions}

All authors were involved in the design of the study and preparation of the manuscript to be submitted. EM conducted the actual study, the statistical analysis, write up and manuscript preparation. All authors read and approved the submitted version of the manuscript and they are accountable for all aspects of the work in ensuring that questions related to the accuracy or integrity of any part of the work are appropriately investigated and resolved.

\section{Competing interests}

The authors declare that they have no competing interests.

\section{Consent for publication}

Not applicable.

Ethical approval and consent to participate

The experimental protocols using laboratory animals were requested to and approved by the Institutional Review Board, University of Gondar.

Received: 8 October 2015 Accepted: 29 July 2016

Published online: 05 August 2016

\section{References}

1. Guerrant RL, Van Gilder T, Steiner TS, et al. Practice guidelines for the management of infectious diarrhea. Clin Infect Dis. 2001;32:331-51.

2. Thielman NM, Guerrant RL. Acute infectious diarrhea. N Engl J Med. 2004;350:38-47

3. Mehmooda MH, Siddiqia HS, Gilani AH. The antidiarrheal and spasmolytic activities of Phyllanthus emblica are mediated through dual blockade of muscarinic receptors and Ca2+ channels. J Ethnopharmacol. 2011;133:856-65.

4. Boschi-Pinto C, Velebit L, Shibuya K. Estimating child mortality due to diarrhoea in developing countries. Bull World Health Organ. 2008;86:710-7.

5. Hamer DH, Simon J, Thea D, Keusch GT. Childhood diarrhea in Sub-Saharan Africa. Child Health Research Project Special Report. 1998.

6. UNICEF. Pneumonia and diarrhea. Tackling the deadliest diseases for the world's poorest children. New York, USA. 2012 
7. Gilani AH, Rahman A. Trends in ethnopharmacology. J Ethnopharmacol. 2005;100(1-2):43-9

8. Azaizeh H, Saad B, Cooper E, Said O. Traditional Arabic and Islamic medicine, a re-emerging health aid. J Evid Based Complementary Altern Med. 2010;7(4):419-24.

9. Syder JD, Merson $\mathrm{MH}$. The magnitude of the global problems of acute diarrheal disease: a review of active surveillance data. Bulletin of the WHO. 1982;60:605-13.

10. Kidane $B$, van Andel T, van der Maesen $L G$, Asfaw Z. Use and management of traditional medicinal plants by Maale and Ari ethnic communities in southern Ethiopia. J Ethnobiol Ethnomed. 2014;10:46.

11. Giday M, Asfaw Z, Woldu Z. Medicinal plants of the Meinit ethnic group of Ethiopia: an ethnobotanical study. J Ethnopharmacol. 2009;124:513-21.

12. Teklehaymanot Tand Giday M. Ethnobotanical study of medicinal plants used by people in Zegie Peninsula, Northwestern Ethiopia. J Ethnobiol Ethnomed. 2007;3:12.

13. Giday M, Asfaw Z, Woldu Z, Teklehymanot T. Medicinal plant knowledge of the Bench ethnic group of Ethiopia: an ethnobotanical investigation. J Ethnobiol Ethnomed. 2009:5:34-41.

14. Megersa M, Asfaw Z, Kelbessa E, Beyene A, Woldeab B. An ethnobotanical study of medicinal plants in Wayu Tuka District, East Welega Zone of Oromia Regional State, West Ethiopia. J Ethnobiol Ethnomed. 2013;9:68-72.

15. Giday M. An ethnobotanical study of medicinal plants used by the Zay people in Ethiopia. CBM:s Skriftserie 3:81-99. Uppsala 2001

16. Birru EM, Abdelwuhab M, Shewamene Z. Effect of hydroalcoholic leaves extract of Indigofera spicata Forssk. on blood glucose level of normal, glucose loaded and diabetic rodents. BMC Complement Altern Med. 2015;15:321.

17. Pérez $L B$, Li J, Lantvit $D D$, Pan $L$, Ninh TN, Chai $H$, et al. Bioactive constituents of Indigofera spicata. J Nat Prod. 2013;76:1498-504.

18. Pérez $L B$, Still $P C$, Naman $C B$, Ren $Y$, Pan $L$, Chai $H$, et al. Investigation of Vietnamese plants for potential anticancer agents. Phytochem Rev. 2014;13:727-39.

19. Dilebo J. Antibacterial activities of Microglossa pyrifolia (Lamk.)Kuntze, Leucas deflexa Hook. and Indigofera spicata Forssk. IJPSR. 2015;6(5):865-8.

20. Nieto N, Lopez-pedrosa TM, Mesa MD, Torres MI, Fernandez MI, Rios A, et al. Chronic diarrhea impairs intestinal antioxidant defense system in rats at weaning. Digestive Disease and Sciences. 2000;45(10):124.

21. Han X, Pang Y, Liu S, Tan Z, Tang S, Zhou C, et al. Antidiarrheal and antioxidant activities of Honokiol extract from magnolia officinalis cortex in mice. Trop J Pharm Res. 2014;13(10):1643.

22. Mora A, Paya M, Rios JL, Alcaraz MJ. Structure activity relationships of polymethoxy flavones and other flavonoids as inhibitors of nonenzymic lipid peroxiation. Biochem Pharmacol. 1990;36:317-22.

23. Longanga Otshudi A, Vercruysse A, Foriers A. Contribution to the ethnobotanical, phytochemical and pharmacological studies of traditionally used medicinal plant in the treatment of dysentery and diarrhea in Lomela area, Democratic Republic of Congo (DRC). J Ethnopharmacol. 2000;71(3):411-23.

24. Belemtougri RG, Constantin B, Cognard C, Raymond G, Sawadogo L. Effects of two medicinal plants Psidium guajava L. (Myrtaceae) and Diospyros mespiliformis $L$. (Ebenaceae) leaf extracts on rat skeletal muscle cells in primary culture. J Zhejiang Univ Sci B. 2006;7(1):56-63.

25. Institute for Laboratory Animal Research (ILAR). Guide for the care and use of laboratory animals. 8th ed. Washington DC: National Academic Press; 2011.

26. OECD: Guidelines for the testing of chemicals; Acute oral toxicity: up and down procedures. OECD Publishing; 2008. http://www.oecdbookshop.org, No 425. Adopted December 2008. No 425. Accessed 28 June 2015.

27. Trease GE, Evans WC. A textbook of pharmacognosy. 13th ed. London: Bailliere Tindall; 1989. p. 176-80.

28. Tiwari P, Kumar B, Kaur M, Kaur G, Kaur H. Phytochemical screening and extraction: a review. Internationale Pharmaceutica Sciencia. 2011;1(1):98-106.

29. Shoba FG, Thomas M. Study of antidiarrhoeal activity of four medicinal plants in castor-oil induced diarrhoea. J Ethnopharmacol. 2001;76(1):73-6.

30. Franca CS, Menezes FS, Costa LCB, Niculau ES, Alves PB, Pinto JE, Marcal RM. Analgesic and antidiarrheal properties of Ocimum selloi essential oil in mice. Fitoterapia. 2008;79(7-8):569-73.
31. Abu Mohammed TI, Muhammad EU, Asharf UC, Mominur R, Razibul H, Atiar R. In vivo antidiarrheal and cytotoxic potential of different fractions of Pandanus Foetidus leaves. Am J Biomed Sci. 2013;5(3):208-16.

32. Akah PA, Orisakwe OE, Gamaniel KS, Shittu A. Evalaution of Nigerian traditional medicine II: Effects of some Nigerian folk remedies on peptic ulcer. J Ethnopharmacol. 1998;62:123-7.

33. Gerhard VH. Drug discovery and evaluation, pharmacological assays (2nd edn.), Springer -Verlag Berlin Heidelberg, New York; 2002. 875-76 p

34. Tadesse WT, Hailu AE, Gurmu AE, Mechesso AF. Experimental assessment of antidiarrheal and antisecretory activity of $80 \%$ methanolic leaf extract of Zehneria scabra in mice. BMC Complement Altern Med. 2014;14:460.

35. Utiérrez SP, Mendoz DZ, Munive AH, Martínez AM, González CP, Mendoza ES. Antidiarrheal activity of 19-deoxyicetexone isolated from Salvia ballotiflora Benth in mice and rats. Molecules. 2013;18:8895-905.

36. Hammond AC. Animal well-being in pharmacology and toxicology research. J Anim Sci. 1994;72:523-7.

37. Pearn $\mathrm{JH}$, Hegarty MP. Indospicine the teratogenic factor from Indigofera spicata extract causing cleft palate. Br J Exp Path. 1970;51:34.

38. Li Y, Li C, Xu Q, Kang W. Antioxidant, a-glucosidase inhibitory activities in vitro and alloxan-induced diabetic rats protective effect of Indigofera stachyodes Lindl. root. J Med Plants Res. 2012;6(9):1524-31.

39. Fletcher MT, Rafat AM, Jassim A, Cawdell-Smith AJ. The occurrence and toxicity of indospicine to grazing animals. Agriculture. 2015;5:427-40.

40. Schiller LR. Review article: anti-diarrheal pharmacology and therapeutics. Aliment Pharmacol Ther. 1995;9(2):87-106.

41. Neimegeers CTE, Awouters F, Janssen PAJ. The castor oil test in rats: an in vivo method to evaluate antipropulsive and antisecretary activity of Antidiarrheals. Drug Dev Res. 1984;4:223-7.

42. Wojcikowski K, Wohlmuth H, Johnson DW, Rolfe M, Gobe G. An in vitro investigation of herbs traditionally used for kidney and urinary system disorders: potential therapeutic and toxic effects. Nephrology (Carlton). 2009;14:70-9.

43. Parekh J, Chanda S. In-vitro antimicrobial activities of extracts of Launaea procumbens Roxb. (Labiateae), Vitis vinifera L. (Vitaceae) and Cyperus rotundus L. (Cyperaceae). AJBR. 2006;9:89-93.

44. Sarker SD, Latif Z, Gray Al. Metheds in biotechnology. Natural products isolation. 2nd ed. Totowa: Humana Press; 2006. p. 269-73.

45. Tanko Y, Hayatu Z, Mohammed A, Goji AD, Musa KY, Yerima M. Effect of residual aqueous portion of hydro-methanolic leaves extract of Indigofera Pulchra on blood glucose levels of alloxan-induced diabetic Wistar rats. Int J Anim Veter Adv. 2009;1 (1):18-21.

46. Umer S, Tekewe A, Kebede N. Antidiarrhoeal and antimicrobial activity of Calpurnia aurea leaf extract. BMC Complement Altern Med. 2013;13:21.

47. Venkatesan N, Thiyagarajan V, Narayanan S, Arul A, Raja S, Kumar SGV, Rajarajan T, Perianayagam JB. Antidiarrheal potential of Asparagus racemous wild root extracts in laboratoire animals. J Pharm Pharmaceut Sc. 2005;8(1):39-45

48. Goodman SL, Gilman A. The pharmacological basis of therapeutics. 9th ed. Health Professional Division, New York, USA: McGrow-Hill Publishers; 1996. 927 p

\section{Submit your next manuscript to BioMed Central and we will help you at every step:}

- We accept pre-submission inquiries

- Our selector tool helps you to find the most relevant journal

- We provide round the clock customer support

- Convenient online submission

- Thorough peer review

- Inclusion in PubMed and all major indexing services

- Maximum visibility for your research

Submit your manuscript at www.biomedcentral.com/submit 